\title{
Beneath the Surface of Civil Recourse Theory
}

\section{MARTHA CHAMALlaS*}

As a torts professor, I find much to admire in civil recourse theory as conceived by John Goldberg and Benjamin Zipursky (G \& Z). I particularly like the fact that their theory gives a certain upgraded stature to the field, configured in their writings as one of the basic pillars of our legal system, right up there with contract law and property. ${ }^{1}$ As a progressive scholar, I am also drawn to the rhetoric of rights, accountability, and empowerment $\mathrm{G} \& \mathrm{Z}$ employ in weaving their narrative of civil recourse. It is a language familiar to left-leaning reformers who struggle to make the law more responsive to the needs of vulnerable people, while avoiding a patronizing, condescending tone of "protection," "sympathy," or "pity."2 On the surface, civil recourse theory thus seems compatible with a social justice orientation to torts, a refreshing change from the drumbeat of efficiency and bloodless cost-benefit analyses that still characterize the dominant law and economics approach to this area of law.

Once you scratch the surface, however, I fear that G \& Z's civil recourse theory turns out not to hold that much promise for those of us who have progressive aspirations for tort law beyond a defense of the status quo. ${ }^{3}$ This limitation is largely due to the fact that $G \& Z$ 's civil recourse theory takes no account of the importance of group identity in tort law's historical construction of wrongs and injuries and continues to miss the skewing of interests that characterizes the structure of mainstream U.S. tort doctrine. Instead, like many of its predecessors, civil recourse theory is built around a model of an abstract, disembodied individual who acts and responds apart from social context. Largely oblivious to critical theory and to the contributions of critical scholars over the last several decades, civil recourse theory strikes me as an updated version of classical legal theoryelegant, but a bit too formal for my taste.

At the moment, civil recourse theory is not a "school of thought" in the sense of an intellectual movement, with a number of leaders and adherents, such as law and economics or legal feminism. Instead, it is still largely the invention of G \& Z, two hugely prolific scholars who have articulated, refined, and applied their theory in any number of major law review articles. For those conversant in tort theory and doctrine, the capstone article that lays out everything you need to know about civil

* Robert J. Lynn Chair in Law, Moritz College of Law, The Ohio State University. Many thanks to John and Ben for giving us this opportunity to reflect on their wonderful body of work and to Mike Rustad and my fellow panelists for organizing and participating on the panel.

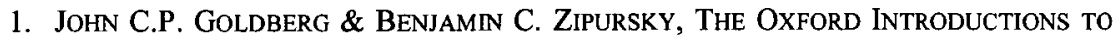
U.S. LAW: TORTS 64 (2010).

2. See Anne Bloom with Paul Steven Miller, Blindsight: How We See Disabilities in Tort Litigation, 86 WASH. L. REV. 709 (2011) (urging legal actors in torts cases to move away from a narrative of pity and tragedy to one of rights and empowerment).

3. Of course, defending the status quo has become a major task in this age of defendant-oriented tort reform. On this score, civil recourse theory can provide useful arguments to plaintiffs resisting cutbacks in liability and damages. See John C.P. Goldberg \& Benjamin C. Zipursky, Torts as Wrongs, 88 TEX. L. REV. 917, 980-83 (2010). 
recourse theory is Torts as Wrongs, published in the Texas Law Review in $2010 .^{4}$ If you are looking for a simpler statement of their theory, however, I highly recommend G \& Z's Oxford Introduction to U.S. Tort Law also published in 2010.5 In that treatise, the authors introduce the reader to Tort Law's Gallery of Wrongs, a rich, accessible tour of torts, in the plural. I can tell you that each room in that Gallery is beautifully designed and appointed and that the treatise is not just useful for first-year law students.

It is not so easy to locate G \& Z's scholarship within contemporary tort theory. By their own account, civil recourse theory stands in sharpest contrast to law and economics (L \& E): for example, G \& Z are highly critical of L \& E's instrumental, ahistorical approach to torts which measures the value of a tort rule by an external standard of efficiency and wealth maximization. For the uninitiated, civil recourse theory may seem indistinguishable from corrective justice theory-after all, both approaches emphasize rights and wrongs, use a language of morality, and are fixed on the bilateral relationship between injurer and injured. ${ }^{6}$ But $G \& Z$ have also taken pains to distinguish their civil recourse theory from the theories of major corrective justice scholars and are not content simply to align themselves with that alternative school of thought that has positioned itself as the major competitor to law and economics. ${ }^{7}$

For my lights, I find it most helpful to characterize Goldberg and Zipursky as today's version of classical legal theorists whose primary aim is to reveal the inner logic of tort law. By classical legal theory, I am referring here to Duncan Kennedy's idea of a specific mode of thinking about the law-sometimes referred to as a "legal consciousness", — which gained ascendancy in the mid-nineteenth century and dominated legal discourse well into the early twentieth century. As Kennedy describes it, classical legal thought, first and foremost, sees law as a system with "strong internal structural coherence." Given this overriding feature, it is understandable that classical legal theorists would spend a great deal of effort trying to discern how a particular body of law "hangs together" and would also be interested in the flip side of coherence, that is, in showing how a particular body of law is "distinctive" and set apart from other bodies of law. ${ }^{10}$ In addition to this

4. Id.

5. GOLDBERG \& ZIPURSKY, supra note 1.

6. See id. at 69 ("Our views on large-scale questions about the nature and purposes of tort law are much closer to those of corrective justice theorists than economists.").

7. Id. at 68-69 (citing differences between civil recourse theory and corrective justice accounts); see generally Benjamin C. Zipursky, Civil Recourse, Not Corrective Justice, 91 GEO. L.J. 695 (2003).

8. Duncan Kennedy, Three Globalizations of Law and Legal Thought: 1850-2000, in The New Law and Economic Development: A Critical Appraisal 19 (David M. Trubek \& Alvaro Santos eds., 2006). Kennedy is careful to point out that a "legal consciousness" is not the same as an "ideology," the former being fluid enough to contain a variety of possible political projects. $I d$. at 28 . Nevertheless, classical legal theory is often associated with conservative ideology because "a large majority of the juristic elite that developed and propagated CLT [classical legal theory] was conservative." Id.

9. Id. at 25 .

10. See John C.P. Goldberg, Tort in Three Dimensions, 38 PEPP. L. REV. 321, 329 (2011) (describing torts as "distinctive legal creatures"). 
fascination with internal coherence, classical legal theory, according to Kennedy, is characterized by three other prominent traits: (1) "elaboration of the distinction between private and public," (2) "individualism," and (3) "commitment to legal interpretive formalism." 11

By these criteria, G \& Z's civil recourse theory clearly qualifies as classical legal theory. I should stress that this characterization of civil recourse theorydespite its vague suggestion of "been there, done that"-is not meant to denigrate the enterprise. Starting in the 1980s, there has been a resurgence of classical legal thinking in a variety of fields and many influential scholars are drawn to it. ${ }^{12}$ However, for readers from a critical theory background, I merely wish to point out that the feeling they may have that there is something very old and very familiar about G \& Z's approach is not without foundation. G \& Z are not embarrassed to reach far back to position their theory: they cite Blackstone, Locke, and even the Declaration of Independence as supports for civil recourse theory, ${ }^{13}$ preferring to rely on these old pedigrees rather than to search for newer, external explanations, such as frame analysis ${ }^{14}$ or social and cognitive psychology, ${ }^{15}$ to illuminate the forces shaping contemporary tort law.

As $G \& Z$ characterize it, civil recourse theory is descriptive or interpretive, rather than normative or prescriptive. Their theory purports to delineate the central features of tort law as it "is," without sliding into an account of tort law as it "ought to be." As mentioned above, G \& Z's separation of the descriptive (or interpretive) from the normative (or prescriptive) is a hallmark of classical legal theory. Tellingly, you will not find $\mathrm{G} \& \mathrm{Z}$ arguing that tort law ought to be reshaped to respond to pressing social realities or injustices, a mode of reasoning and argument alien to classical theorists and more aligned with legal theories (which Kennedy dubs "the social") that developed later in the twentieth century. ${ }^{16}$ Instead, G \& Z set out on a mission to explain, not to persuade, or in Goldberg's words, to present "a clear-eyed view of the thing being studied." 17 And, most important for our purposes, there is little acknowledgment in G \& Z's writings that a description that resonates may end up actively shaping the law, rather than simply mapping its contours. Although $\mathrm{G} \& \mathrm{Z}$ are masterful in framing their subject, they do not pause to reflect on the importance of framing to our understanding of the thing being studied.

11. Kennedy, supra note 8, at 25.

12. Id. at 59 (referring to the "puzzling 'resurgence' of CLT after 1980").

13. John C.P. Goldberg, Tort Law at the Founding, 39 FLA. ST. U. L. REV. 85, 88 (2011).

14. For a discussion of the importance of "framing" in the development of tort law, see Timothy D. Lytton, Clergy Sexual Abuse Litigation: The Policymaking Role of Tort Law, 39 CONN. L. REV. 809, 818-23 (2007).

15. See, e.g., Jon Hanson \& Michael McCann, Situationist Torts, 41 LoY. L.A. L. REv. 1345 (2008) (eschewing the importance of formal tort doctrine and using social psychology and the mind sciences to explain the forces that shape contemporary tort law).

16. Kennedy, supra note 8, at 38-39 (describing the "is to ought" rhetoric of the social legal consciousness).

17. Goldberg, supra note 10 , at 322. 
Despite its abstract nature, civil recourse theory, like most compelling narratives, has a main protagonist who propels the narrative forward. For civil recourse theory, this central character or image is the empowered tort victim who responds to injury by seeking vindication of his rights. The first thing I noticed about this image is that it is very active and very muscular. Variously, this individual is described as exercising a kind of vigorous agency, as someone who responds, vindicates, retaliates. This bearer of rights, of course, is no stranger to mainstream U.S. legal discourse. Rather, he is the updated version of the familiar masculine subject of liberal theory, ${ }^{18}$ now depicted as "empowered" rather than simply "autonomous." What is surprising is to find this empowered individual in a new context. Needless to say, tort victims are not usually portrayed as powerful agents but are more often cast as victims of misfortune and misconduct who must contend with the involuntary trauma and disruption that frequently follows tortious events.

The empowered tort victim of civil recourse theory is also a very privatized image. I must confess that at first I was confused by the idea that it was the tort victim who "responded" to the injury. I am used to saying and thinking that it is the law that "responds" to injury by providing a tort remedy. In my language - a language inherited from Legal Realism - the "response" we are focused upon is a public response in which the state does more than provide a forum or venue for a private dispute. G \& Z's placement of the empowered tort victim at the center of their narrative upends the Realist story of an active state that provides protection for its citizens. In civil recourse theory, by way of contrast, the role of the tort victim overshadows the role of the state, even though the state is the entity responsible for the creation and implementation of the rules and machinery of the civil justice system. Although $G \& Z$ do not dispute this crucial, public aspect of tort law, the rhetoric of civil recourse theory downplays the significance of the state and casts private individuals as the primary actors. Insofar as tort law has a function for $G \& Z$, it is also an intrinsically private one, namely, "alter[ing] the power relationship between private persons by empowering victims to assert claims against, and to obtain satisfaction from, tortfeasors." ${ }^{19} \mathrm{G} \& \mathrm{Z}$ disapprove of even a metaphorical public role for the torts plaintiff, strongly disputing the conception of plaintiffs as "private attorneys general." 20 In their account, the state properly recedes from the stage, leaving the individuals largely to settle the score for themselves.

Although it has its roots in nineteenth century classical legal theory, G \& Z's civil recourse theory also fits comfortably with a twenty-first century neoliberal vision of a downsized "public," which outsources most of the heavy lifting to the private sector. Admittedly, definitions of neoliberalism are notoriously variable and vague. However, they all can be said to share in the basic belief that the state should be accorded only a minimal role in economic and cultural life, leaving as

18. Two classic articles dissecting the masculine subject of liberal theory from a feminist perspective are Kathryn Abrams, Sex Wars Redux: Agency and Coercion in Feminist Legal Theory, 95 COLUM. L. REV. 304 (1995) and Robin West, Jurisprudence and Gender, 55 U. CHI. L. REV. 1 (1988).

19. GOLDBERG \& ZIPURSKY, supra note 1, at 69.

20. See Goldberg, supra note 10, at 327. 
much as possible up to individuals to interact in free and self-regulating markets. ${ }^{21}$ Neoliberal accounts of human behavior also frequently infuse individuals with a "transactional logic," depicting such individuals as "rational and fully responsible entrepreneurial actors," defined by their capacity for self-care and bearing full responsibility for their actions. ${ }^{22} I$ do not mean to suggest that $G$ \& $Z$ 's empowered tort victim is somehow synonymous with the economic-minded risk manager who emerges from neoliberal theory. Nevertheless, the two accounts bear some similarities: each posits a minimal state, accords center stage to a self-sufficient individual, and displays a decided preference for the private. This is why, despite their protestations of political neutrality, ${ }^{23} \mathrm{G} \& \mathrm{Z}$ 's civil recourse theory will probably continue to code as "conservative" to many readers.

My main concern with civil recourse theory rests with this central image of the empowered tort victim. Do not get me wrong. I very much like the idea of an empowered tort victim, and I share G \& Z's view that tort suits can be politically empowering. ${ }^{24}$ But as an account of contemporary tort law, it is simply too rosy a description. It does not speak to or say much about the disempowerment out there in the real world of injured persons who find themselves unable to recover for many of the most serious recurring injuries in their lives. For many potential tort claimants from less privileged groups-particularly women, racial and ethnic minorities, and low-income persons - tort law has not yet delivered on this promise of empowerment. Instead, to use G \& Z's metaphor, injuries disproportionately suffered by these groups are either not pictured in Tort Law's Gallery of Wrongs or receive only marginal protection. I am here thinking about injuries of sexual and racial harassment and exploitation, reproductive injuries connected to pregnancy and fertility, domestic violence, and relational harm involving damage and destruction to important intimate relationships.

In our book, The Measure of Injury: Race, Gender, and Tort Law, ${ }^{25}$ my coauthor, Jennifer Wriggins, and I catalogue many of the hidden biases in tort law that we argue have resulted in a devaluation of claims of particular importance to marginalized groups, even though we recognize that tort law can-and sometimes does - promote social equality. We mainly part company with $\mathrm{G} \& \mathrm{Z}$ by our "glass is half empty" reaction to contemporary tort law. In their less critical view, G \& Z applaud civil recourse theory for resting on the bedrock notion of "where there's a right, there's a remedy." 26 To be able to make such a claim, however, G \& Z must not regard tort law's spotty record in protecting the rights of marginalized groups as a major shortcoming of this body of law. In contrast to scholars who fault tort law

21. See David Harvey, A Brief History of Neoliberalism 2, 65 (2005).

22. See Lise Gotell, Rethinking Affirmative Consent in Canadian Sexual Assault Law: Neoliberal Sexual Subjects and Risky Women, 41 AKRON L. REV. 865, 874-76 (2008), discussed in Martha Chamallas, Introduction to Feminist Legal Theory 307 (3d ed. 2012).

23. See Goldberg, supra note 10 , at 333 (claiming that there is nothing "inherently miserly" nor "inherently progressive" about civil recourse theory).

24. Id. at 334.

25. Martha Chamallas \& Jennifer B. Wriggins, The Measure of Injury: Race, GENDER, AND TORT LAW (2010).

26. Goldberg \& Zipursky, supra note 3, at 973 (footnote omitted). 
for replicating and sometimes deepening hierarchies and inequalities in the larger culture, G \& Z's civil recourse narrative tends to depict the development of tort law as being more even-handed, as neutrally selecting which harms to recognize as legal wrongs based on consensus norms.

At the outset, it is important to recognize that G \& Z's theory is more than just description. It invariably does more than simply "make sense of the tort law we have." ${ }^{27}$ Here is where we need a little critical theory to illuminate classical legal theory. Critical theory warns that a strict separation of interpretation and prescription is impossible, that the descriptive/normative dichotomy is inherently unstable. This is because, as social psychologists often tell us, the human process of interpreting and describing the world cannot free itself from considerations of what that world ought to be. ${ }^{28}$ An assertion of common sense-or a claim that an interpretation "makes sense" of the law-is not simply a discoverable fact but also a claim to authority that simultaneously describes and constructs reality. ${ }^{29}$

In this respect, theories that claim to be mere description share the same infirmity as purportedly objective accounts of human events that claim to be merely factual: they each ignore the importance of perspective to a person's understanding of those events. As one civil rights scholar summed up this central observation: "[i]n the best tradition of critical theory, the scholarly literature has demonstrated that there is no neutral baseline from which we can evaluate social experience. Rather, our baselines are invariably shaped by our experiences. ${ }^{\prime 30}$ From the social science side, scholars such as Dan Kahan and his "social cognition" collaborators have repeatedly shown how a person's cultural worldview may interact with gender and race to influence how such a person interprets facts and evaluates risk, ${ }^{31}$ a finding that seems highly relevant to the development of tort law. At a time when many scholars are busy documenting the deep perceptual divides in our society that affect causal judgments and assessments of danger, ${ }^{32} \mathrm{G} \& \mathrm{Z}$ 's classical approach makes little attempt to theorize the impact of cultural polarization and differing perspectives on the development of tort law. I should point out that I am not the

27. John C.P. Goldberg, Twentieth-Century Tort Theory, 91 GEO. L.J. 513, 515 (2003) (defining interpretive tort theories).

28. See, e.g., Eric D. Knowles \& Peter H. Ditto, Preference, Principle, and Political Casuistry, in IDEOLOGY, PSYCHOLOGY, AND LAW 341 (Jon Hanson ed., 2012) (describing how people act inconsistently, unconsciously concealing preference in principle).

29. Chamallas \& WRIGGINS, supra note 25 , at 18.

30. See Michael Selmi, Comment, Subtle Discrimination: A Matter of Perspective Rather than Intent, 34 COLUM. HUM. RTs. L. REV. 657, 661 (2003) (footnote omitted); see also Kennedy, supra note 8 , at 71 (noting that "the interpretive modes are no less value saturated for having eschewed prescription").

31. See Dan M. Kahan, Donald Braman, John Gastil, Paul Slovic \& C.K. Mertz, Culture and Identity-Protective Cognition: Explaining the White-Male Effect in Risk Perception, $4 \mathrm{~J}$. EMPIrical Legal STUD. 465 (2007); Dan M. Kahan, Culture, Cognition, and Consent: Who Perceives What, and Why, in Acquaintance-Rape Cases, 158 U. PA. L. REV. 729 (2010); Dan M. Kahan, David A. Hoffman \& Donald Braman, Whose Eyes Are You Going to Believe? Scott v. Harris and the Perils of Cognitive Illiberalism, 122 HARV. L. REv. 837 (2009).

32. See, e.g., Martha Chamallas, Gaining Some Perspective in Tort Law: A New Take on Third-Party Criminal Attack Cases, 14 LEWIS \& CLARK L. REV. 1351, 1361-72 (2010) (discussing studies on multiple perspectives). 
first writer to assert that civil recourse theory is not merely descriptive. In an early critique of G \& Z's work, Jane Stapleton called the theory's descriptive claims "problematic" and argued that "[h]ad Goldberg and Zipursky placed more emphasis on the fact that the analytical arrangement of legal concepts is a matter of choice rather than inherently mandated, they may have seen that their project is a normative one: to persuade lawyers to choose the conceptual arrangements Goldberg and Zipursky prefer."33

As an interpretive theory, civil recourse theory is susceptible to a status quo bias. ${ }^{34}$ When $\mathrm{G} \& \mathrm{Z}$ describe the inner logic of tort law, you get the feeling that they pretty much like what they see-after all, it's logical. This theoretical starting point makes arguing for change all the more difficult. We know that in an inherently conservative field such as law, which honors precedent, a descriptive theory that claims to "make sense of the law" has a great rhetorical advantage over an avowedly normative theory that makes a case for change and acknowledges its agency in attempting to rewrite the law. As one feminist critic explains, the persuasiveness of such descriptive arguments (which she calls "arguments from immanence") are "greatly enhanced" because they "proceed on the basis that what is contended for-a principle, priority, or meaning - is in fact already there; indeed (preferably) has always been there in the first place."35 She goes on to explain that, despite its strategic advantages, feminist critics of the law often find it difficult to adopt such a style of argument. Many feminists realize that "it is not so long since tort law expressly conceived women in property terms" and are led to question "how can it now be argued that a notion of personhood which accords them full respect and equal recognition has always been there?"36 It is for this reason that I resist G \& Z's presentation of their theory as interpretive and prefer to think of civil recourse theory-with its emphasis on the empowered tort victim-as more aspirational than descriptive.

To get down to specifics, my chief objection to civil recourse theory is that it misses the built-in bias embedded in the deep structures of tort law. ${ }^{37}$ Like popular

33. Jane Stapleton, Evaluating Goldberg and Zipursky's Civil Recourse Theory, 75 FORDHAM L. REV. 1529, 1532 (2006) (footnote omitted).

34. See Joanne Conaghan, Tort Law and Feminist Critique, 56 Current Legal Probs. 175, 208 (2003) (identifying the "discursive convention" of mainstream torts scholarship that accords "an excessive deference to coherence," reinforcing "the conceptual and ideological status quo" (emphasis in original)).

35. Id. at 207.

36. Id. (footnote omitted).

37. I first developed the idea of hidden bias in the deep structures of tort law in Martha Chamallas, The Architecture of Bias: Deep Structures in Tort Law, 146 U. PA. L. REV. 463 (1998). In my work, I use a broad definition of "bias [that] includes both deliberate and unconscious disparities in the treatment of persons who are similarly situated, whether stemming from animus, hostility, insensitivity, lack of empathy, or the use of stereotypes or unfair generalizations about a group." Id. at 466. This broad conception of bias also captures "disparate impact" bias, referring to the use of facially neutral practices, doctrines, or policies that have an adverse effect on a social group and are not justified by competing interests or concerns, as well as "cognitive bias," the use of categories (such as types of injuries or types of damages) that are devalued because of their cognitive association with women, minorities, and other marginalized social groups. See CHAMALlas \& WRIGGINS, 
culture, it treats gender, race, and class bias largely as if they were things of the past, equating formal equality with gender and race equity. Tort law passes the formal equality test because married women and former slaves may now sue in their own right, and there are few explicit gender or racial distinctions in tort doctrine. ${ }^{38}$ In their treatise, for example, $G \&$ Z tell the stock story of a tort law that used to be patriarchal and racist but has since reformed itself by "open[ing the] courthouse doors to plaintiffs who previously lacked access to them," presumably upon passage of the married women's property acts and the abolition of slavery. ${ }^{39}$ With the exception of their questionable classification of Title VII sexual harassment claims as statutory tort actions (more on this point later), G \& Z's civil recourse theory pays little attention to the legacy of slavery, segregation, and coverture that still resides in tort law. In contrast to critical theory, there is no examination of the degree to which tort law adequately addresses harms flowing from subordination or whether group identity matters in the recognition of legally actionable claims or in their valuation.

Although $G \& Z$ acknowledge that tort law is selective in recognizing and vindicating interests-- that not all wrongs are pictured in the Tort Law's Gallery of Wrongs- they are not primed to see this selectivity as tied to deep-seated cultural biases and the systematic devaluation of the interests of certain social groups. Rather, they depict tort law as protecting a set of basic interests, framed at a high level of generality, without really questioning whether the historical articulation of these interests has been expansive enough to cover the most serious recurring injuries that befall different social groups or has actually translated into viable legal claims for all those affected. In this commentary, I focus on two such basic interests identified by $G \& Z:^{40}$ what they denominate as the interest in Bodily Integrity and the interest in Personal Space. According to $G \& Z$, the first interest undergirds and gives meaning to tort claims for battery and negligence, ${ }^{41}$ while the second interest is tied to claims for assault, false imprisonment, intentional infliction of emotional distress, and workplace harassment. ${ }^{42}$ You will note that these interests largely map onto tort claims for physical and emotional harms, respectively, with negligent infliction of emotional distress falling through the cracks.

Like other mainstream approaches, civil recourse theory largely just accepts that in the tort hierarchy of types of harm, physical harm is privileged over emotional and relational harm. As the new Restatement (Third) of Torts makes clear, physical

supra note 25 , at $24-25,27$.

38. One important exception to the formal equality regime of tort law is the continued use of explicit race and gender-based tables used to predict the amount of economic damages a tort victim may receive in personal injury and death cases. See CHAMALlaS \& WRIGGiNs, supra note 25 , at 158-70 (discussing calculation of lost future income).

39. GOLDBERG \& ZIPURSKY, supra note 1, at 20-21.

40. Id. at $36-39$. G \& Z's list of basic interests additionally includes Possessory Interests, Freedom of Contract and Choice, and Standing in the Eyes of Others, interests not relevant for this essay.

41. Id. at $30-33$. The interest in Bodily Integrity is also cited as support for products liability claims and strict liability claims for abnormally dangerous activities, claims not addressed in this essay.

42. Id. at 34-36. 
harms, even of the trivial sort, are supposed to be fully protected against invasion, ${ }^{43}$ while emotional harms are approached more skeptically and qualify as deserving of compensation only if they fall within one of the traditional intentional tort categories or meet restrictive rules governing recovery for intentional or negligent infliction of emotional distress. ${ }^{44}$ Relational harms, such as loss of consortium for the injury or death of intimate family members, are treated as marginal, collateral claims, as mere appendages to claims for physical or emotional harms. Thus, the existence of a hierarchy of types of harms is clear and should be appreciated by any student of tort law. However, while civil recourse theory is fixed on explaining how this ranking system is coherent or makes sense, critical theory provides the tools for gaining a deeper understanding of the hierarchy and leads us to ask more probing questions. It does this first by unmasking the ranking of harms as a social construction, a human invention reflective not only of consensus cultural norms, but what also may be thought of as hegemonic norms, norms that track the interests and values of privileged social groups. Thus, feminist and critical race scholars commonly want to discover who benefits from (or who is disadvantaged by) such a ranking and they frequently interrogate the basic categories themselves, asking, for example, just what counts as "physical harm."

A case in point: historically, the canonical cases that formed the basis for the tort of negligent infliction of emotional distress involved pregnant female plaintiffs who suffered miscarriages and stillbirths as a result of fright. ${ }^{45}$ Their claims, however, were classified as emotional distress claims because women's reproductive injuries were not then represented within the not-so-neutral category of physical harm. In my scholarship, I cite the "fright-caused" physical harm cases as a prime example of cognitive bias-the injuries in such cases, whether heart attacks or miscarriages, were treated as emotional harms in part because the prototypical plaintiffs in such cases were pregnant women, a cognitive move that reinforced the gendered character of the entire category of emotional harm. ${ }^{46}$ So cast as emotional injuries, the claims were legally precarious, often dismissed as too intangible to warrant recovery.

Although the Restatement (Third) of Torts now finally takes the position that a shock-induced miscarriage is to be regarded as a physical harm, ${ }^{47}$ there is still no secure recovery for many reproductive injuries, such as a loss of fertility, wrongful birth, or loss of reproductive choice. ${ }^{48}$ This gap in coverage is largely because many courts continue to have a difficult time conceptualizing the relationship between a pregnant woman and her fetus, in particular seeing and categorizing the distinctive connection between a mother and a fetus. The intertwined physical, emotional, and relational nature of the response of a woman who experiences a

43. See Restatement (ThiRd) of TORTS: Liability for Physical AND EMOtional HARM $\S \S 4-6(2005)$.

44. See id. at $\S \S 45-48$.

45. See Martha Chamallas with Linda K. Kerber, Women, Mothers, and the Law of Fright: A History, 88 Mich. L. REV. 814 (1990).

46. Chamallas, supra note 37 , at 521-26.

47. Restatement (ThiRd) OF TORTS: Liability for Physical and EMotional HaRm $§$ $113(2010)$.

48. Chamallas \& Wriggins, supra note 25 , at 102-12, 128-38. 
miscarriage or stillbirth does not fit neatly into the blunt physical/emotional dichotomy constructed by tort law. This means that courts in the United States still resist comprehending women's reproductive injuries as invasions of bodily integrity, with the result that they are liable to be relegated to the disfavored realm of emotional distress claims. Noting a similar reaction from courts in the United Kingdom, Joanne Conaghan complains that "judges seem perennially flummoxed by the injurious implications of pregnancy, leading them to classify miscarriage as a form of nervous shock, and involuntary motherhood as pure economic loss." 49 Thus, tort law's "common sense" demarcation line between physical and emotional harm is not only a medical and scientific anachronism, ${ }^{50}$ but continues to serve as a barrier to claims of particular importance to women. ${ }^{51}$ The basic interest in bodily integrity, it turns out, is not all-inclusive and, I would argue, requires closer scrutiny than civil recourse theory has yet offered.

Another stark example of the non-neutral character of tort law is its record on domestic violence. Despite the fact that domestic violence is one of the leading causes of injury among women, domestic violence tort claims are still exceedingly rare. ${ }^{52}$ Recovery is hindered because of a variety of potent procedural obstacles, such as short statutes of limitation and joinder rules requiring that such claims be brought at the time of divorce, and, perhaps most importantly, the lack of insurance for this type of recurring injury. ${ }^{53}$ As a practical matter, neither the existence of the long-standing tort claims for assault, battery, and false imprisonment, nor the newer, supposedly more capacious claim for intentional infliction of emotional distress has done much to vindicate domestic violence victims' rights to bodily integrity and freedom from oppression.

At the level of theory, there is still some tendency to steer domestic violence cases out of torts and to treat domestic violence as a matter for family law, as just a species of marital discord inseparable from other disagreements that typically surface during a breakup. This domain anxiety about handling domestic violence through tort law is reinforced by the tendency to privilege negligence claims-seen as the core of tort law-over intentional torts, another implicit hierarchy in law. All told, the preoccupation with "accidents" has rendered domestic violence largely invisible within the frame of tort law, ${ }^{54}$ even as the problem has gained prominence

49. Conaghan, supra note 34 , at 190 (footnote omitted).

50. Betsy J. Grey, Neuroscience and Emotional Harm in Tort Law: Rethinking the American Approach to Free-Standing Emotional Distress Claims, in 13 CURRENT LEGAL Issues (Michael Freeman ed., 2011), available at http://ssm.com/abstract=1499989.

51. See Prue Vines, Mehera San Roque \& Emily Rumble, Is "Nervous Shock" Still a Feminist Issue? The Duty of Care and Psychiatric Injury in Australia, 18 TORT L. REV. 9, 16-18 (2010) (empirical study of Australian tort cases from 1885-2008 revealing a preponderance of female plaintiffs in psychiatric harm cases and concluding that the claim's historical identification with women "reduces its authenticity in the eyes of society and the law").

52. See Chamallas \& WRiggins, supra note 25 , at $67-68$ (for example, in 2003 there were only thirty-four reported domestic violence tort cases, compared to roughly two million injuries per year).

53. Id. at $68-76$.

54. However, feminist scholars have long critiqued the low-profile of domestic violence 
in the larger culture. Although $G \& Z$ clearly disapprove of the centering of negligence law and consequent neglect of intentional torts, ${ }^{55}$ they provide no critique of tort law's dismal record on domestic violence. Certainly, tort law's failure to respond to domestic violence does not square with the promise of civil recourse to vindicate serious invasions of interpersonal rights. This huge gap in the law is explainable only if we step outside of classical legal theory and appreciate the strong cultural resistance to providing an effective remedy against intimate violence.

With respect to civil recourse theory and relational harms, I should start by noting that $\mathrm{G} \& \mathrm{Z}$ regard civil recourse theory as being relational in structure, as grounded in the binary relationship between injurer and victim. However, this kind of relational framework should not be confused with relational theories that are most familiar to critical and feminist scholars. Importantly, civil recourse theory bears little kinship to relational (a.k.a. cultural) feminism, a theoretical approach that starts from the proposition that human beings are connected and interdependent. ${ }^{56}$ Relational feminists typically argue that the law places too low a value on "caring for others" and that caregiving and nurturing ought to be given the same importance in the law as self-reliance and autonomy. They stress that individuals need others to survive and flourish, emphasizing that autonomy is not an inborn trait of human beings but a capacity that must be nurtured and supported, often by intimate relationships. ${ }^{57}$

In contrast, civil recourse theory is highly individualistic and abstract. It deals with conceptual relationships, for example whether there is a conceptual link between a defendant's action and plaintiff's injury (think Palsgraf ${ }^{8}$ ) and ironically does not readily comprehend relational injury, meaning the injury that flows from damage to or destruction of important intimate relationships. Thus, in their treatise, $\mathrm{G} \& \mathrm{Z}$ find somewhat "mysterious" the willingness of modern courts to allow recovery for close relatives in bystander emotional distress claims, ${ }^{59}$ such as in the famous case of Dillon $v$. Legg, ${ }^{60}$ where a mother witnessed her child killed before her eyes. Under civil recourse theory, it is difficult to find a duty owed to the plaintiff mother because she suffered no direct physical injury. In their treatment of the case, $G \& Z$ adopt the traditional classification of the mother in Dillon as a

within torts. See Clare Dalton, Domestic Violence, Domestic Torts and Divorce: Constraints and Possibilities, 31 New ENG. L. REV, 319 (1997); Jennifer B. Wriggins, Domestic Violence Torts, 75 S. CAL. L. REV. 121 (2001).

55. Goldberg \& Zipursky, supra note 3, at 955 (challenging "the intellectual framework that treats tort law as coextensive with negligence law").

56. In U.S. tort law, Leslie Bender has produced the best-known relational feminist scholarship. See Leslie Bender, A Lawyer's Primer on Feminist Theory and Tort, $38 \mathrm{~J}$. Legal EDUC. 3 (1988); Leslie Bender, Feminist (Re)Torts: Thoughts on the Liability Crisis, Mass Torts, Power, and Responsibilities, 1990 DUKE L.J. 848 (1990). For a general discussion of relational (or cultural) feminism, see CHAMALLAS, supra note 22, at 55-72 (discussing the foundational writings of Carol Gilligan, Carrie Menkel-Meadow, and Robin West).

57. See Conaghan, supra note 34, at 203-04 (citing Jennifer Nedelsky, Reconceiving Autonomy: Sources, Thoughts and Possibilities, 1 YALE J.L. \& FEMINISM 7, 10 (1989)).

58. Palsgraf v. Long Island R.R. Co., 162 N.E. 99 (N.Y. 1928).

59. GOLDBERG \& ZIPURSKY, supra note 1 , at 133.

60. 441 P.2d 912 (Cal. 1968). 
"bystander" and echo the concerns many courts have expressed about opening the flood gates of liability and providing a principled stopping point for liability.

In my view, offering a convincing rationale for recovery in a case such as Dillon is so difficult precisely because tort law devalues relational harm, a feature of the law that works to the detriment of women who still provide the lion's share of caregiving work in our culture. Prevailing tort doctrines provide only skimpy protection against even the most grievous relational injuries, with many states restricting loss of consortium recovery to cases involving injury to spouses, rather than granting the claim to all close family members. ${ }^{61}$ If Dillon were repositioned as a relational injury case, however, it would become an easy case on the merits because of the paramount importance of the parent-child relationship at issue in that case. For this reason, we have argued that situating Dillon under the heading of negligent infliction of emotional distress is misguided and that "bystander" claims of this sort should be approached head-on as claims for relational loss and afforded to all close family members, whether or not they witness the accident. ${ }^{62}$ Suffice it to say that Margery Dillon's combined relational/emotional harm would be readily understood by a relational feminist who would likely rank her injury as one of the more devastating harms a person could experience, even if civil recourse theory struggles with the damage to this real, rather than conceptual, relationship.

My final points relate to civil recourse theory and harms of subordination, specifically how $\mathrm{G} \& \mathrm{Z}$ approach tort law and employment discrimination. It is on this issue that our differing half empty/half full reactions to tort law come most sharply into focus. In a nutshell, I regard tort law's record of addressing workplace harassment as inadequate, as providing only modest, supplemental protection to tort plaintiffs in some states. ${ }^{63}$ Additionally, I am still waiting to witness a fundamental shift in tort law's conception of dignity and dignitary harm, from an old-fashioned, masculine conception of dignity as honor, to a more egalitarian conception of "dignity as equality," as the right to be treated as a "full member of the polity, not excluded, subordinated or denigrated." 64 In contrast, G \& Z's civil recourse theory presents a much rosier picture in which torts has already provided considerable relief to sexual harassment victims. To take this position, $G$ \& $\mathrm{Z}$ stretch the definition of tort law beyond conventional common law boundaries, making the questionable move of characterizing Title VII statutory civil rights claims as tort claims or extensions of tort claims. ${ }^{65}$ In the process, they miss the powerful cultural forces that keep civil rights and torts separate and apart. As someone who has argued in favor of the "migration" of civil right principles into

61. See Chamallas, supra note 37 , at 500-02.

62. See Chamallas \& Wriggins, supra note 25 , at 113-17.

63. See Martha Chamallas, Discrimination and Outrage: The Migration from Civil Rights to Tort Law, 48 WM. \& MARY L. REv. 2115 (2007).

64. See id. at 2175-76; see also Reva B. Siegel, Dignity and the Politics of Protection: Abortion Restrictions Under Casey/Carhart, 117 YALE L.J. 1694, 1736-45 (2008) (discussing three meanings of "dignity").

65. See GOLDBERG \& ZIPURSKY, supra note 1, at 196; Goldberg \& Zipursky, supra note 3 , at 935,985 . 
tort law, ${ }^{66}$ I wish tort law were that responsive to subordination harms, but it is simply not yet the case.

There are currently many obstacles to bringing a tort claim for workplace harassment. First off, some states cut off such claims altogether, ruling that tort claims for civil rights violations are preempted by the existence of state antidiscrimination laws or by exclusivity provisions in state workers' compensation statutes. ${ }^{67}$ The biggest barrier to tort harassment claims, however, comes from tort doctrine itself, specifically the extraordinarily narrow scope generally given to the tort of intentional infliction of emotional distress. A large number of states, probably a majority, set the bar of proof so high that they allow recovery only in extremely aggravated cases that do not resemble the typical hostile work environment cases. Even when the sexual or racial harassment is repeated, severe, and by any account, abusive, these courts have denied recovery for intentional infliction of emotional distress due to a lack of "extreme and outrageous" behavior. ${ }^{68}$ Such decisions have the effect of cordoning off torts from dignitary harms arising from discriminatory treatment, refusing any relief to plaintiffs who are unable to shoehorn their claims into the traditional categories of assault, battery, false imprisonment, or slander. In such jurisdictions, the intentional infliction tort is a mere "gap filler," allowed only in rare instances, preferably when no other remedy is available. Notably, only a minority of "liberal" states allow workplace harassment claims to be brought more routinely as intentional infliction claims. ${ }^{69}$ These states take the position that tort claims for sexual and racial harassment provide mutual reinforcement of the state's important public policies, namely, the state's policy against group-based discrimination.

The denial of a tort claim for workplace harassment has practical, as well as theoretical, repercussions. That a plaintiff may have a Title VII damages remedy is by no means the end of the analysis. First, under prevailing federal case law, Title VII does not permit a claim to be pursued against the individual harasser; instead, Title VII claims are brought solely against employers. ${ }^{70}$ Significantly, courts regard Title VII as imposing a form of enterprise liability, with claims properly levied against the entity and aimed primarily at deterring future violations. ${ }^{71}$ Despite

66. See Chamallas, supra note 63; Martha Chamallas, Civil Rights in Ordinary Tort Cases: Race, Gender, and the Calculation of Economic Loss, 38 LoY. L.A. L. REV. 1435 (2005).

67. Because Title VII itself contains an express anti-preemption clause, defendants must find other bases for their preemption arguments. See Chamallas, supra note 63, at 2135-38.

68. See Chamallas \& Wriggins, supra note 25 , at 79 (discussing egregious sexual and racial harassment that did not qualify as "outrageous" behavior); Chamallas, supra note 63 , at 2128-32.

69. Chamallas, supra note 63, at 2133-35.

70. See, e.g., Miller v. Maxwell's Int'1, Inc., 991 F.2d 583 (9th Cir. 1993) (no personal liability of employees under Title VII).

71. In sexual harassment suits, employers are generally afforded an affirmative defense to liability if they can prove that they have taken reasonable care to prevent harassment and the victim did not report internally. See Burlington Indus., Inc. v. Ellerth, 524 U.S. 742 (1998). By so encouraging the development of internal reporting systems, the U.S. Supreme Court has placed paramount importance on prevention of harassment, rather than compensating victims. 
recent talk of the tortification of Title VII, ${ }^{72}$ the ban against individual liability stands as a testament to the un-tort-like status and history of Title VII. Second, recovery of damages under Title VII are capped at very low amounts-the statute sets a total cap on a plaintiff's combined compensatory and punitive damages at $\$ 50,000$ to $\$ 300,000$, depending on the size of the employer. ${ }^{73}$ Because most states have set no caps or have set higher caps on tort damages, a harassment plaintiff stands a better chance of securing an adequate recovery in tort. Indeed, a recent empirical study of sexual harassment cases conducted by Catherine Sharkey found that including a tort claim in such cases had the effect of increasing an award on average by $\$ 137,176$, after controlling for independent variables that might affect the level of damages. ${ }^{74}$

In their writings, $G \& \mathrm{Z}$ do not discuss the important differences between statutory civil rights claims and tort actions: instead they simply label Title VII claims "statutory torts" because they fit G \& Z's description of torts as "relational wrongs that give rise to private rights of action." 75 This equation of torts and statutory civil rights actions comes as quite a surprise to feminists who have constructed a very different narrative of the interaction of these two bodies of law. While G \& Z consider the law of sexual harassment to be an "offshoot[] of battery and other long-standing torts," 76 and assert that "sexual-harassment claims began as common law tort claims," argued that tort law had failed miserably to address the harm of sexual harassment that the movement to treat sexual harassment as a form of discrimination under Title VII gained momentum. ${ }^{78}$ Rather than try to remake tort doctrines to accommodate sexual harassment claims, MacKinnon thought it best to free sexual harassment from tort law, give it its own name, and provide it a home in civil rights law. As I understand the history, sexual harassment claims first developed under Title VII and have slowly, very unevenly, begun to migrate into torts. Thus, I would describe workplace harassment not as an old tort but as a new cause of action brought to life by the 1970s women's movement. Until that time, the prevailing "no harm in asking" attitude meant no redress for workplace harassment in any domain. ${ }^{79}$

Tellingly, common law courts historically failed to regard harassment as a "wrong" because they failed to appreciate the social or group dimension of harassment. Specifically, group identity is crucial to sexual and racial harassment

72. See Charles A. Sullivan, Tortifying Employment Discrimination, 92 B.U. L. REv. (forthcoming 2012).

73. 42 U.S.C. $\$ 1981 \mathrm{a}(\mathrm{b})(3)(2006)$.

74. Catherine M. Sharkey, Dissecting Damages: An Empirical Explanation of Sexual Harassment Awards, 3 J. EMPIRICAL LEGAL STUD. 1, 39 (2006).

75. Goldberg \& Zipursky, supra note 3, at 985.

76. GOLDBERG \& ZIPURSKY, supra note 1, at 196.

77. Goldberg \& Zipursky, supra note 3, at 939.

78. See Catharine A. MacKinnon, Sexual harassment of Working Women: A CASE OF SEX DISCRIMINATION 171-74 (1979) (arguing that harassment claims should be redirected away from "the disabling (and cloying) moralism" of tort law).

79. Chamallas, supra note 63 , at $2151-68$ (discussing the tort of outrage prior to civil rights). 
claims, whether they are viewed as civil rights claims or tort actions. This is because harms suffered by harassment victims are not simply individual, personal harms, but injuries that serve simultaneously to devalue the target and her group and to reinforce the inferior and unequal status of both the target and her group. In the past, tort law has been uncomfortable treating plaintiffs as members of social groups, in part because such an approach departs from the image of the plaintiff as an abstract individual who possesses universal rights. ${ }^{80}$ Whether tort law will be able to shed its individualistic character long enough to handle anti-subordination claims, such as claims for sexual and racial harassment, remains to be seen. Unlike G \& Z, I am not ready to declare "victory" and classify Title VII harassment claims as tort claims, particularly when such classification does not mean that harassment plaintiffs are currently able to recover full tort damages against offenders in an action commonly regarded as a tort action.

In the end, it may have been G \& Z's conception of civil recourse theory itself that led them to classify Title VII harassment claims as "statutory torts" and, through this appropriation, to gather evidence of tort law's gradual embrace of a consensus anti-discrimination norm. As I see it, civil recourse theory is a unitary theory that attempts to explain tort law through a single theoretical lens that shows how tort law hangs together. As such, it risks downplaying the complexity and contested nature of the current state of the law. Rather than grapple with the two distinct lines of authority that have emerged to determine whether plaintiffs may bring tort claims for workplace harassment, G \& Z's approach elides the issue by equating Title VII and tort claims. Because civil recourse theory does not address cultural conflict, it does not spend much time on doctrinal splits and the messiness of tort law in general. However, the more one delves into the pocket of the law governing tort recovery for workplace harassment, the messier it gets. What I believe drives the nearly polar-opposite majority and minority views on the subject is not a dispute about tort theories, but a cultural conflict over the extent and seriousness of harassment as an injury and the degree to which workers should be able to hold employers and supervisors accountable for abusive working conditions. As with reproductive harms and relational injuries, to understand this aspect of tort law, one needs to understand the conflict taking place outside of tort law.

In their treatise, $\mathrm{G} \& \mathrm{Z}$ state that the real political question for tort law today is its proper place alongside other bodies of law and other institutions. ${ }^{81} \mathrm{I}$ agree. The "domain" question is of critical importance. But unlike G \& Z, I do not believe that it is time to reinscribe the public/private split by emphasizing the distinctiveness of tort law. Even if it is not their intention, civil recourse theory tends to disconnect torts from norms commonly associated with public law and from larger cultural trends. Critical theory, in contrast, leads scholars to see and to study the permeability of the public/private border and analyze why certain public valuessuch as anti-discrimination norms, sexual autonomy, and reproductive choice-are or are not reinforced through tort law. Some migration of values and norms from

80. See Chamallas \& WRIGGINS, supra note 25 , at 183 ("[T]he individual of tort law has largely been an abstraction, disembodied and living outside society.").

81. GOLDBERG \& ZIPURSKY, supra note 1 , at 6 . 
public to private has already occurred. In my view, this migration should be accelerated toward a goal-perhaps one shared by $\mathrm{G} \& \mathrm{Z} \longrightarrow$ of more closely connecting civil rights to civil wrongs. 